\title{
PENGEMBANGAN MEDIA SCRABBLE UNTUK MENDUKUNG KETERAMPILAN BERBICARA BAHASA JAWA KRAMA SISWA KELAS 5 SD NEGERI 2 PETIR BANTUL
}

\author{
Ulfie Fajri Febriawati, Suharsimi Arikunto \\ Universitas Ahmad Dahlan \\ usimaviemizuna@gmail.com
}

\begin{abstract}
This study aims to develop Javanese learning media for Krama Language material to support speaking skills that can help teachers deliver the material. This research is a research and development $(R \& D)$ using the $4 D($ four-D) development model. This research was conducted on fifth-grade students at SD Negeri 2 Petir Bantul. The product trial subjects are six students, and the trial run is 18 students. This study used instruments in the form of questionnaires and oral tests. The analysis of this research is qualitative and quantitative analysis. The results of the study from expert validation got an average value of 88.76 (Very Good). Product trials were obtained from the responses of teachers and students with grades of 96.88 (Very Good) and 93.33 (Very Good). Students' oral test scores before using the media are 60 (good); then, after using get a value of 95 (Very Good) trial use of the response of teachers and students get a value of 96.63 (Very Good); and 96.97 (Very Good). The oral test of students before using the media is 48.89 (less); after using get a value of 86.11 (Very Good). Overall, data from all assessments of the quality and feasibility of Kramaic Scrabble media are included in the category of Very $\operatorname{Good}(S B)$.
\end{abstract}

Keywords: Learning media, Krama, Scrabble

\begin{abstract}
ABSTRAK
Penelitian ini bertujuan untuk mengembangkan media pembelajaran Bahasa Jawa materi Bahasa Krama untuk mendukung keterampilan berbicara yang dapat membantu guru dalam menyampaikan materi. Penelitian ini yaitu penelitian dan pengembangam $(R \& D)$ menggunakan model pengembangan 4D (four-D). Penelitian ini dilakukan pada siswa kelas lima di SD Negeri 2 Petir Bantul. Subjek uji coba produk 6 siswa dan uji coba pemakaian 18 siswa. Pada penelitian ini digunakan instrumen berupa angket dan tes lisan. Analisis penelitian ini adalah analisis kualitatif dan kuantitatif. Hasil penelitian dari validasi ahli mendapat rata-rata nilai 88,76 (Sangat Baik); uji coba produk diperoleh dari respon gurudan siswa dengan nilai 96,88 (Sangat Baik) dan 93,33 (Sangat Baik); nilai tes lisan siswa sebelum menggunakan media adalah 60 (Baik); kemudian sesudah menggunakan mendapatkan nilai 95 (Baik Sekali) uji coba pemakaian dari respon guru dan siswa mendapatkan nilai 96,63 (Sangat Baik); dan 96,97 (Sangat Baik); tes lisan siswa sebelum menggunakan media adalah 48,89 (Kurang); setelah menggunakan mendapatkan nilai 86,11 (Sangat Baik). Secara keseluruhan data dari semua penilaian terhadap kualitas dan kelayakan media Scrabble Bahasa Krama termasuk dalam kategori Sangat Baik (SB). Kata kunci: Media pembelajaran, Bahasa Krama, Scrabble.
\end{abstract}




\section{PENDAHULUAN}

Pendidikan adalah persoalan yang penting bagi manusia. Pendidikan akan menentukan akan seperti apa siswa itu nanti. Memperoleh pendidikan yang layak akan membuat siswa memiliki bekal untuk hidup bermasyarakat. Seperti yang termuat dalam Undang-Undang Sistem Pendidikan Nasional No. 20 Pasal 1 Ayat 1 tahun 2003, (2011: 3) pendidikan adalah usaha sadar dan terencana untuk mewujudkan suasana belajar dan proses pembelajaran agar peserta didik secara aktif mengembangkan potensi dirinya untuk memiliki kekuatan spiritual keagamaan, pengendalian diri, kepribadian, kecerdasan, akhlak mulia, serta keterampilan yang diperlukan dirinya, masyarakat, bangsa dan negara. Pendidikan dapat dilakukan dengan cara formal dan non formal. Pendidikan formal dapat dilakukan di sekolah oleh guru dalam proses pembelajaran. Pada pembelajaran inilah komponen-komponen seperti rencana pembelajaran, bahan ajar dan media pembelajaran dibutuhkan.

Media pembelajaran adalah komponen penting untuk mencapai tujuan. Media pembelajaran dapat membuat siswa menerima materi dengan lebih mudah. Media juga dapat membuat siswa meresa tertarik serta bersemangat dalam belajar. Arsyad (2016: 3) menyatakan bahwa media dalam proses belajar mengajar cenderung diartikan sebagai alatalat gerafis, fotografis, atau elektronik untuk menangkap, memproses, dan menyusun kembali informasi visual atau verbal. Media pembelajaran juga dapat membuat siswa mampu memahami materi lebih baik, serta dapat membuat materi diingat lebih lama. Perlu diketahui bahwa kegiatan pembelajaran adalah suatu proses komunikasi dengan adanya media maka proses pembelajaran tersebut akan lebih maksimal dengan kata lain maka secara singkat dapat dikemukakan bahwa media pembelajaran itu merupakan wahana penyalur pesan atau informasi belajar (Nurseto, 2011: 20).

Media dibutuhkan untuk semua mata pelajaran tidak terkecuali muatan lokal. Muatan lokal dibutuhkan untuk membekali siswa dengan keterampilan. Permendikbud Nomor 79 Tahun 2014 muatan lokal kurikulum 2013 merupakan bahan kajian atau mata pelajaran pada satuan pendidikan yang berisi muatan dan proses pembelajaran tentang potensi dan keunikan lokal yang dimaksutkan untuk membentuk pemahaman peserta didik terhadap keunggulan dan kearifan di daerah tempat tinggalnya. Muatan lokal diajarkan dengan tujuan membekali siswa dengan sikap, pengetahuan, dan keterampialan yang diperlukan untuk mengenal dan mencintai lingkungan alam, sosial, budaya, dan spiritual di daerahnya, melestarikan dan mengembangkan keunggulan dan kearifan daerah yang berguna bagi dirinya dan lingkungannya dalam rangka menunjang pembangunan nasional. Muatan lokal dapat berupa seni budaya, prakarya, pendidikan jasmani, olahraga, dan kesehatan, bahasa, dan teknologi.

Berdasarkan pengamatan pada Juli 2017 di Sekolah Dasar daerah Sleman dan Bantul pembelajaran Bahasa Jawa tercantum dalam kurikulum muatan lokal yang wajib diikuti oleh siswanya. Pada pembelajaran bahasa Jawa media masih digolongkan kurang. Di SD Negeri 2 Petir media hanya terdapat satu poster ukuran A3 tentang aksara Jawa. Sebagian guru juga melakukan pembelajaran muatan lokal khususnya Bahasa Jawa hanya dengan menggunakan bantuan papan tulis. Pada pembelajaran bahasa Jawa guru melakukan pembelajaran menggunakan metode tanpa menggunakan media. Terkadang guru melakukan diskusi kecil yang mana kebanyakan siswa tidak paham apa yang harus didiskusikan dan saat diajukan pertanyaan mengenai pembelajaran hari tersebut hanya beberapa siswa yang menjawab dengan benar.

Saat pembelajaran di SD Negeri 2 Petir khususnya kelas lima beberapa siswa terlihat tidak tertarik untuk mengikuti atau pun memperhatiakan pembelajaran. Beberapa kali siswa ditegur dan memperhatikan namun tak beberapa lama siswa kembali asik dengan 
temannya. Siswa terlihat lebih suka memainkan alat tulis disekitar mereka atau bermain benda-benda di sekitar kelas.

Siswa juga telihat belum mampu menggunakan Bahasa Jawa dengan tepat. Masih banyak siswa yang tidak bisa menggunakan bahasa Jawa saat berbicara dengan teman atau guru. Artinya siswa belum dapat menggunakan Bahasa Krama dengen benar. Mereka terbiasa menggunakan bahasa Jawa Ngoko karena dalam keseharian baik di rumah ataupun di lingkungan bermainnya para siswa menggunakan Bahasa Jawa Ngoko. Hal tersebut terjadi karena pada saat pembelajaran tentang bahasa Krama kurang mampu menyerap materi pembelajaran tanpa adanya media pembelajaran.

Penggunaan metode pembelajaran yang kurang bervariasi dan minimnya media pembelajaran bahasa Jawa berdampak pada kurangnya pengetahuan siswa mengenai materi pembelajaran bahasa Jawa Krama sehingga mereka kurang mampu berdialog menggunakan Bahasa Jawa dengan benar. Guru maupun siswa memerlukan inovasi dan kreasi dalam media pembelajaran Bahasa Jawa. Inovasi dan kreasi tersebut bertujuan untuk mendukung keterampilan berbicara Bahasa Jawa krama sehingga siswa kelas 5 SD Negeri 2 Petir mampu berkomunikasi menggunakan Bahasa Jawa. Tujuan lain adalah agar bahasa daerah dapat terus dilestarikan.

Media Scrabble dapat dipilih sebagai salah satu media pembelajaran bahasa krama. Media Scrabble adalah permainan papan yang dimainkan dua orang atau lebih yang setiap orangnya akan menyusun kata di papan. Skor diperoleh dari setiap kata yang diisusun pemain dikatakan memenangkan permainan apabila memiliki jumlah skor paling banyak. Media Scrabble dapat dipilih sebagai media pembelajaran Bahasa Krama karena media tersebut cocok untuk menambah kosakata Bahasa Krama dan mendukung keterampilan berbicara siswa. Hal tersebut sejalan dengan tujuan untuk mendukung kualitas pembelajaran dengan menggunakan media pembelajaran serta mendukung keterampilan berbicara bahasa Jawa Krama siswa. Berdasarkan permasalahan tersbut akan dikembangkan Media Scrabble untuk Menambah kosakata bahasa Jawa Krama sehingga dapat mendukung keterampilan berbicara Siswa Kelas 5 SD Negeri 2 Petir.

\section{METODE PENELITIAN}

Penelitian ini merupakan jenis penelitian dan pengembangan atau Research and Development (R\&D) Penelitian dan pengembangan diartikan sebagai cara ilmiah untuk meneliti, merancang, memproduksi dan menguji validitas produk yang telah dihasilkan. Penelitian ini mengacu pada penelitian yang dikembangkan oleh Thiagarajan menggunakan model 4D (Define, Design, Dovelopment, dan Dissemination). Prosedur pengembangan yang akan dilakukan oleh peneliti dalam mengembangkan media pembelajaran Scrabble untuk mendukung keterampilan berbicara siswa Bahasa Jawa Siswa kelas lima SD Negeri 2 petir, yaitu sebagai berikut:

Define (Pendefinisian). Pada langkah ini peneliti melakukan observasi untuk mengumpulkan informasi dari beberapa sumber. Setelah informasi atau data telah diperoleh dan dianggap cukup kemudian peneliti menganalisis kebutuhan yang dapat membantu proses pembelajaran. Kemudian informasi yang didapat oleh peneliti digunakan untuk merencanakan produk yang dikembangkan

Design (perencanaan). Setelah melakukan pendefinisian atau mengumpulkan informasi maka langkah selanjutnya adalah melakukan perencanaan. Pada langkah ini peneliti merencanakan dan mendesain produk Scrabble Bahasa Krama untuk mendukung keterampilan berbicara siswa. Sebelum pembuatan mendesain Scrabble, persiapan yang dilakukan yaitu menyiapkan materi yang dibutuhkan dari buku Remen Basa Jawi kelas 5, 
kemudian membuat desain papan Scrabble, membuat pertanyaan, membuat kartu dolanan scrabble, kunci jawaban kartu dolanan scrabble dan buku panduan menggunakan aplikasi Microsof Word 2010, dan Corel Draw X7.

Dovelopment (pengembangan). Setelah desain Scrabble Bahasa Krama untuk mendukung keterampilan berbicara sudah selesai, maka langkah selaanjutnya yaitu melakukan validasi kepada ahli media, ahli materi, dan ahli pemeblajaran. Validasi ini dilakukan untuk mengetahui kualitas produk yang dikembangkan. Dalam proses validasi para ahli memberikan masukan, komentar, dan saran yang membangun untuk memperbaiki produk. Setelah melakukan revisi dan telah disetujui oleh para ahli, langkah selanjutnya yaitu melakukan uji coba. Uji coba yang dilakukan yaitu uji coba produk (kelompok kecil) dan uji cobapemakaian (kelompok besar). Uji coba produk (kelompok kecil) dilakukan pada siswa kelas lima SD Negeri 2 Petir dengan jumlah 6 siswa yang dipilih berdasarkan kriteria baik, sedang, kurang baik. Pada tahap ini peneliti melakukan proses pembelajaran menggunakan media Scrabble Bahasa Krama kemudian melakukan tes lisan sebelum dan sesudah penggunaan media dan menyebarkan angket respon siswa dan guru. Selanjutnya jika uji coba produk (kelompok kecil) dirasa sudah cukup maka pada langkah berikutnya yaitu dilakukan uji coba pemakaian (kelompok besar). Uji coba pemakaian (kelompok besar) dilakukan pada siswa kelas lima SD Negeri 2 Petir dengan jumlah 18 siswa. Pada tahap ini sama dengan tahap sebelumnya.

Penyebaran (disseminate). Tahap penyebaran merupakan suatu tahap akhir penelitian pengembangan ini. Tahap ini bertujuan agar produk media pembelajaran dapat dimanfaatkan oleh orang lain. Tahap penyebaran yang dilakukan peneliti yaitu dengan cara mengemas dan memberikan media pembelajaran hasil pengembangan kepada sekolah tidak disebar secara masal.

Subjek Penelitian

Setelah produk dinyatakan layak oleh ahli media, ahli materi dan ahli pembelajaran peneliti melakukan uji coba pada sabjek uji coba yaitu pada siswa kelas lima SD. Uji coba ini dilakukan pada siswa kelas lima SD Negeri 2 Petir. Teknik pemilihan sampel yang digunakan untuk uji coba pada penelitian ini menggunakan Purposive Sampling. Menurut Siregar (2014: 148) Purposive Sampling adalah teknik pengambilan sempel berdasarkan kriteria-kriteria tertentu.

A. Jenis Data

Jenis data yang digunakan dalam penelitian pengembangan ini adalah data kualitatif yang dilengkapi dengan data kuantitatif. Data kualitatif diperoleh dari kritik, tanggapan dan saran dari uji validasi desain produk, uji coba produk dari para ahli dan kelompok kecil yang berupa tanggapan, kritikdan saran untuk bahan revisi produk yang dikembangkan. Data kuantitatif diperoleh dari kuesioner yang diisi oleh ahli media pembelajaran dan ahli pembelajaran , ahli materi dan siswa yang ikut dalam uji coba kelompok kecil kemudian data dari tes yang diikuti oleh siswa untuk media Scrabble yang sedang dikembangkan.

B. Instrument Pengumpulan Data

Instrument pengumpulan data penelitia pengembangan media Scrabble untuk mendukung ketrampilan berbicara Bahasa Jawa Krama Siswa Kelas 5 SD Negeri 2 
Petir adalah lembar validasi, lembar angket respon untuk siswa angket respon untuk guru dan tes untuk siswa skala yang digunakan dalam penelitian ini adalah skala likert dengan menggunakan empat tingkatan yaitu (1) sangat tidak sesuai, (2) tidak sesuai, (3) sesuai, (4) sangat sesuai.

C. Teknis Analisis Data

Penelitian pengembangan ini menggunakan teknik analisis data untuk mengolah data yang diperoleh yaitu menggunakan data kualitatif dan data kuantitatif. Analisis Data Kualitatif diperoleh dari proses pengembangan produkhingga manjadi produk jadi serta kritik, tanggapan dan saran dari uji validasi desain produk, uji coba produk. Data tersebut diperoleh dari para ahli dan kelompok kecil yang berupa tanggapan, kritikdan saran untuk bahan revisi produk yang dikembangkan.

Analisis data kuantitatif digunakan untuk mengolah data yang diperoleh dari hasil pengisian lembar observasi oleh ahli media, ahli materi, guru dan angket respon siswa. analisis ini dilakukan dengan menghitung nilai yang diperoleh dari penilai. Data dihasilkan dengan mengguanakan skala likert. Untuk menskor skala kategori Likert, jawaban diberi bobot atau disamakan dengan nilai kuantitatif , 4, 3, 2, 1, untuk empat pilihan pernyataan positif dan 1, 2, 3 ,4, untuk pernyataan yang bersifat negatif (Siregar, 2014: 138). Berdasarkan pernyataan tersebut, tabel Skala Likert adalah dalam penilaian yang digunakan yaitu 4 untuk sangat sesuai, 3 untuk sesuai, 2 untuk tidak sesuai, serta 1 untuk sangat tidak sesuai.

Apabila sudah diperoleh nilai dengan rumus diatas kemudian ditafsirkan penilaian tersebut kedalam kategori, kemudian ditafsirkan penilaian tersebut kedalam kategori sangat baik, baik, cukup, kurang baik/sesuai, dan sangat tidak baik, sesuai dengan pendapat Widoyoko (2013: 242) sebagai berikut:

Tabel 1. Kategori Penilaian

\begin{tabular}{ccc}
\hline Nilai & Klasifikasi & Skor \\
\hline $\mathrm{n}>80$ & Baik Sekali & 5 \\
\hline $60<\mathrm{n} \leq 80$ & Baik & 4 \\
\hline $40<\mathrm{n} \leq 60$ & Cukup & 3 \\
\hline $20<\mathrm{n} \leq 40$ & Kurang & 2 \\
\hline $\mathrm{n} \leq 20$ & Sangat & 1 \\
& Kurang &
\end{tabular}

Berdasarkan kategori diatas akan diketahui hasil dari kelayakan media Scrabble untuk mendukung keterampilan berbicara bahasa karma siswa kelas 5 SD Negeri 2 Petir. Media media Scrabble ini dikatakan layak digunakan apabila nilai yang diperoleh lebih dari 60 .

\section{HASIL DAN PEMBAHASAN}

A. Hasil Uji Coba

Data uji coba penelitian ini berupa data kualitatif dan data kuantitatif. Data kualitatif diperoleh berdasarkan komentar, kritik dan saran dari ahli media, ahli materi dan ahli pembelajaran. Data kuantitatif diperoleh dari penilaian validasi ahli media, ahli materi, ahli pembelajaran, angket respon siswa, dan lembar respon guru.

1. Data Hasil Valiasi ahli

Validasi ahli media terhadap media Scrabble Bahasa Krama dilakukan oleh seorang dosen PGSD yang memiliki kompetensi pada bidang media pembelajaran. Penilaian yang dilakukan adalah penilaian terhadap kualitas media Scrabble Bahasa Krama yang dikembangkan dari segi Validasi media pembelajaran. 
Penilaian dilakukan dengan mengisi lembar validasi ahli media. Hasil penilaian ahli media terhadap aspek kualitas media pembelajaran Bahasa Jawa dengan Scrabble Bahasa Krama mendapat nilai 77,63. Apabila dikonversikan ke dalam data kuantitatif maka termasuk kategori Baik. Dari nilai yang telah didapatkan maka dapat disimpulkan bahwa kualitas media Scrabble Bahasa Krama Baik.

2. Validasi Ahli Materi

Validasi ahli materi terhadap media Scrabble Bahasa Krama dilakukan oleh seorang dosen yang memiliki kompetensi pada bidang materi Bahasa Jawa sekolah dasar. Penilaian yang dilakukan adalah penilaian terhadap kualitas media Scrabble Bahasa Krama yang dikembangkan dari segi materi pembelajaran.Penilaian dilakukan dengan mengisi lembar validasi ahli materi. Hasil penilaian ahli materi terhadap aspek kualitas media pembelajaran Bahasa Jawa dengan Scrabble Bahasa Krama mendapat nilai 95,59. Apabila dikonversikan ke dalam data kuantitatif maka termasuk kategori Baik Sekali. Dari nilai yang telah didapatkan maka dapat disimpulkan bahwa kualitas media Scrabble Bahasa Krama Baik Sekali.

3. Validasi Ahli Pembelajaran

Validasi ahli materi terhadap media Scrabble Bahasa Krama dilakukan oleh seorang dosen yang memiliki kompetensi pada bidang pembelajaran tematik dengan kurikulum 2013. Penilaian yang dilakukan adalah penilaian terhadap kualitas media Scrabble Bahasa Krama yang dikembangkan dari segi pembelajaran. Penilaian dilakukan dengan mengisi lembar validasi ahli pembelajaran. Hasil penilaian ahli pembelajaran terhadap aspek kualitas media pembelajaran Bahasa Jawa dengan Scrabble Bahasa Krama mendapat nilai 93,06. Apabila dikonversikan ke dalam data kuantitatif maka termasuk kategori Baik Sekali. Dari nilai yang telah didapatkan maka dapat disimpulkan bahwa kualitas media Scrabble Bahasa Krama Baik Sekali.

Keseluruhan penilaian oleh validator media, materi, pembelajaran dapat dilihat pada Tabel 2 berikut.

Tabel 2. Hasil Penilaian Ahli

\begin{tabular}{ccc}
\hline Penilaian & Nilai & Kategori \\
\hline Ahli Media & 77,63 & Baik \\
\hline Ahli Materi & 95,59 & Baik Sekali \\
\hline Ahli Pembelajaran & 93,06 & Baik Sekali \\
\hline Rata-rata & 88,76 & Baik Sekali \\
\hline
\end{tabular}

Berikut disajikan dalam bentuk diagram hasil penilaian oleh ahli media, ahli materi, ahli pembelajaran

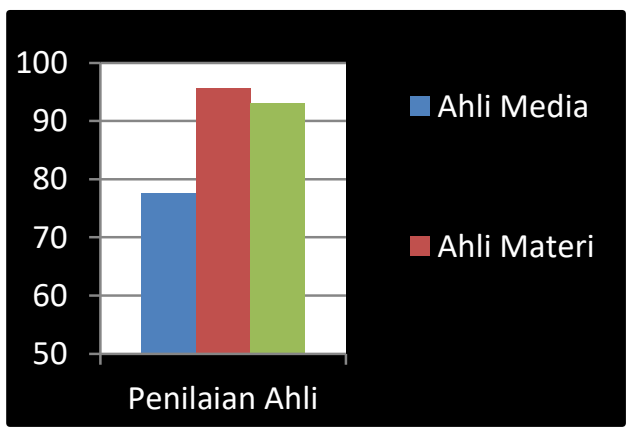

Gambar 1. Diagram Batang Penilaian Para Ahli 
1. Data Hasil Uji Coba Produk

Uji coba produk dilakukan pada hari Senin 30 April 2018. Kepada 6 orang siswa kelas lima SD Negeri 2 Petir terhadap media pembelajaran Scrabble Bahasa Krama. Uji coba produk dilakukan dengan memberikan angket respon siswa dan guru serta tes lisan.

a. Respon Siswa

Hasil respon siswa terhadap media pembelajaran Bahasa Jawa dengan Scrabble Bahasa Krama mendapat nilai 96,88. Apabila dikonversikan ke dalam data kuantitatif maka termasuk kategori Baik Sekali. Dari nilai yang telah didapatkan maka dapat disimpulkan bahwa media Scrabble Bahasa Krama Baik Sekali.

b. Respon Guru

Hasil respon guru terhadap media pembelajaran Bahasa Jawa dengan Scrabble Bahasa Krama mendapat nilai 93,33. Apabila dikonversikan ke dalam data kuantitatif maka termasuk kategori Baik Sekali. Dari nilai yang telah didapatkan maka dapat disimpulkan bahwa media Scrabble Bahasa Krama Baik Sekali

c. Tes Lisan

Hasil tes lisan sebelum dan sesudah yang dilakukan siswa terhadap media Scrabble Bahasa Krama, diketahui skor yang diperoleh sebelum menggunakan media sebanyak 360. Kemudian setelah mengunakan media skor yang diperoleh adalah 570 dari total maksimal skor 600, sehingga nilai yang diperoleh adalah 60 (Baik) dan 95 (Baik Sekali)Hasil tes lisan sesudah menggunakan media yang dilakukan siswa terhadap media pembelajaran Bahasa Jawa dengan Scrabble Bahasa Krama mendapat nilai 95. Apabila dikonversikan ke dalam data kuantitatif maka termasuk kategori Baik Sekali. Dari nilai yang telah didapatkan maka dapat disimpulkan bahwa media Scrabble Bahasa Krama Baik Sekali sebagai media pembelajaran untuk mendukung keterampilan berbicara.

Berikut ini table data kuantitatif yang diperoleh dari respon sebagai berikut:

Tabel 3. Hasil Respon Siswa dan Guru

\begin{tabular}{ccc}
\hline Penilaian & Nilai & Kategori \\
\hline Respon Siswa & \multirow{2}{*}{96,88} & $\begin{array}{c}\text { Baik } \\
\text { Sekali }\end{array}$ \\
Uji Coba Produk & & Baik \\
Respon Guru & \multirow{2}{*}{93,33} & $\begin{array}{c}\text { Sekali } \\
\text { Uji Coba Produk }\end{array}$ \\
\hline
\end{tabular}

Berikut disajikan dalam bentuk diagram hasil penilaian dari tes lisan sebelum dan sesudah menggunakan media pada ujicoba produk.

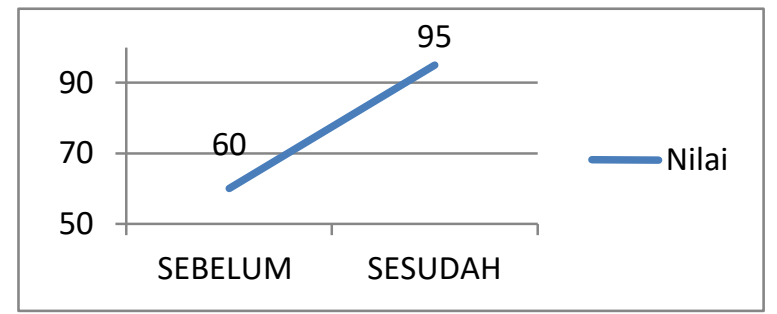

Gambar 2. Hasil Tes Lisan Sebelum dan Sesudah Menggunakan Media 
2. Data Hasil Uji Coba Pemakaian

Uji coba pemakaian dilakukan pada hari Senin 7 Mei 2018. Kepada 18 orang siswa kelas lima SD Negeri 2 Petir terhadap media pembelajaran Scrabble Bahasa Krama. Uji coba pemakaian dilakukan dengan memberikan angket respon siswa dan guru serta tes lisan.

a. Respon Siswa

Hasil respon siswa terhadap media pembelajaran Bahasa Jawa dengan Scrabble Bahasa Krama mendapat nilai 88,37. Apabila dikonversikan ke dalam data kuantitatif maka termasuk kategori Baik Sekali. Dari nilai yang telah didapatkan maka dapat disimpulkan bahwa media Scrabble Bahasa Krama Baik Sekali.

b. Respon Guru

Hasil respon guru terhadap media pembelajaran Bahasa Jawa dengan Scrabble Bahasa Krama mendapat nilai 96,67. Apabila dikonversikan ke dalam data kuantitatif maka termasuk kategori Baik Sekali. Dari nilai yang telah didapatkan maka dapat disimpulkan bahwa media Scrabble Bahasa Krama Baik Sekali.

c. Tes Lisan

Hasil tes lisan sebelum dan sesudah menggunakan media Scrabble Bahasa Krama, diketahui skor yang diperoleh sebelum menggunakan media sebanyak 880. Kemudian setelah mengunakan media skor yang diperoleh adalah 1550 dari total maksimal skor 1800, sehingga nilai yang diperoleh adalah 48,89 (Cukup) dan 86,11 (Baik Sekali). Hasil tes lisan sesudah menggunakan media yang dilakukan siswa terhadap media pembelajaran Bahasa Jawa dengan Scrabble Bahasa Krama mendapat nilai 86,11. Apabila dikonversikan ke dalam Data kuantitatif maka termasuk kategori Baik Sekali. Dari nilai yang telah didapatkan maka dapat disimpulkan bahwa media Scrabble Bahasa Krama Baik Sekali sebagai media pembelajaran untuk mendukung keterampilan berbicara.

Berikut ini table data kuantitatif yang diperoleh dari respon sebagai berikut:

Tabel 4. Hasil Respon Siswa dan Guru

\begin{tabular}{ccc}
\hline Penilaian & Nilai & Kategori \\
\hline Respon Siswa Uji Coba Pemakaian & 96,63 & Baik Sekali \\
\hline Respon Guru Uji Coba Pemakaian & 96,97 & Baik Sekali \\
\hline
\end{tabular}

Berikut disajikan dalam bentuk diagram hasil respon siswa dan respon guru

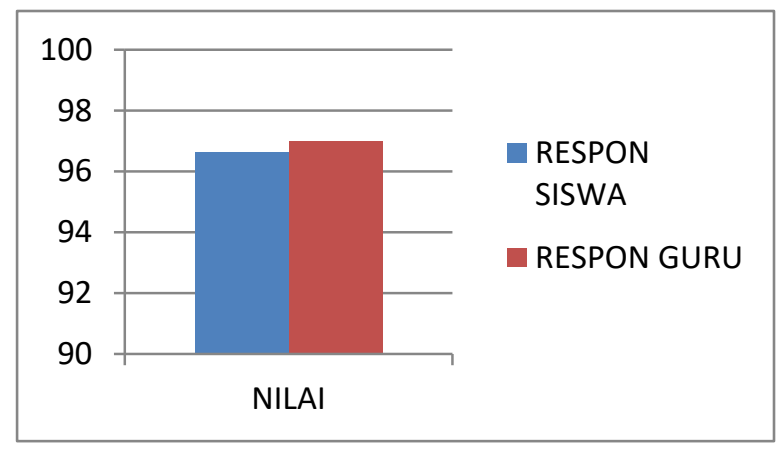

Gambar 3. Diagram Batang Respon Siswa dan Guru

Berikut table tes lisan sebelum dan sesudah menggunakan media : 
Table5. Hasil Tes Lisan Sebelum dan Sesudah Menggunakan Media

\begin{tabular}{lccc}
\hline No & Penilaian & Nilai & Kategori \\
\hline 1. & Sebelum menggunakan media & 48,89 & Cukup \\
\hline 2. & Sesudah menggunakan media & 86,11 & $\begin{array}{c}\text { Baik } \\
\text { sekali }\end{array}$ \\
\hline
\end{tabular}

Berikut disajikan dalam bentuk diagram hasil penilaian dari tes lisan sebelum dan sesudah menggunakan media pada uji coba pemakaian

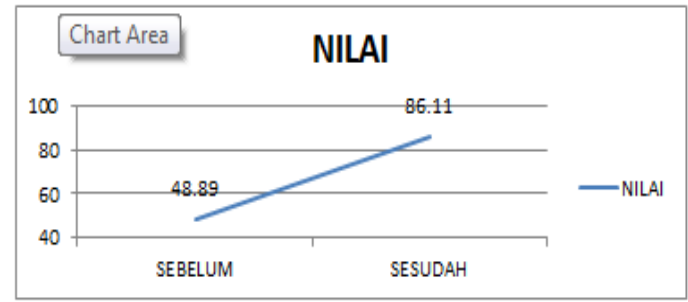

Gambar 4. Hasil Tes Lisan Sebelum dan Sesudah Menggunakan Media

Analisis Data

Analisis data dilakukan setelah melakukan validasi, uji coba produk dan uji coba pemakaian. Dalam penelitian ini analisis data yang dilakukan berupa analisis pengisian angket dari ahli media, ahli materi, dan ahli pembelajaran. Analisis data dilakukan pula pada angket respon siswa dan guru serta tes lisan terhadap media pembelajaran Bahasa Jawa dengan media Scrabble Bahasa Krama.

Analisis Data Kualitatif

a. Analisis Ahli Media

Kritik dan saran tersebut adalah background pada media dibuta sejalan dengan materi (Bahasa Jawa). Papan Scrabble dicetak menggunkan stiker ivory. Lapisi media dengan plastic pelindung. Buku panduan dibuat seperti buku dengan ukuran minimal A5.

b. Analisis Ahli Materi

Adapun saran dan kritik yang diberikan oleh ahli media adalah perbanyak pertanyaan dalam media, ubah penulisan e sesuai dengan kaidah penulisan dalam Bahasa Jawa, dan kesalahan penulisan

c. Analisis Ahli Pembelajaran

Adapun saran dan kritik yang diberikan oleh ahli media adalah ubah identitas dalam RPP sesuai dengan kaidah penulisan RPP kurikulum 2013. Tambahkan tema di RPP yang diambil dari buku bahasa Jawa Fokuskanlah pembelajaran pada siswa.

d. Analisis Uji Coba Produk

Pada uji coba produk guru memberikan komentar yaitu penggunaan media pembelajaran sudah sesuai dan tepat. Tidak hanya guru tetapi siswa juga memberikan komentar dan saran. Komentar dan saran siswa adalah permainannya sangat asik dan seru saya dapat, bermain sambil belajar dan saya menyukai permainan ini karena bisa belajar sambil bermain

e. Analisis Uji Coba Pemakaian

Guru memberikan komentar yaitu penggunaan media pembelajaran sudah sesuai materi yang diajarakan. Tidak hanya guru tetapi siswa juga memberikan komentar dan saran mereka. Komentar dan saran siswa adalah saya sangat suka bermain 
dengan Scrabble dan saya mendapat ilmu Bahasa Krama baru saya suka dengan permainan Scrabble karena ada pelajaran Matematika dan Bahasa Jawanya.

f. Analisis data kuantitatif

Berdasarkan hasil perhitungan nilai yang telah dilakukan maka akumulasi kelayakan Media media Scrabble Bahasa Krama untuk mendukung keterampilan berbicara siswa kelas lima SD Negeri 2 petir dari semua penilai dapat dilihat dalam bentuk tabel sebagai berikut:

Table 6. Penilaian Keseluruhan

\begin{tabular}{cccc}
\hline No & Penilaian & Nilai & Kategori \\
\hline 1. & Ahli Media & 77,63 & Baik \\
\hline 2. & Ahli Materi & 95,56 & Baik Sekali \\
\hline 3. & Ahli Pembelajaran & 93,06 & Baik Sekali \\
\hline 4. & Respon Siswa Uji Coba Produk & 96,88 & Baik Sekali \\
\hline 5. & Respon Guru Uji Coba Produk & 93,33 & Baik Sekali \\
\hline 6. & $\begin{array}{c}\text { Tes Lisan Sesudah Menggunakan } \\
\text { Media Uji Coba Produk }\end{array}$ & 95 & Baik Sekali \\
\hline 7. & Respon Siswa Uji Coba Pemakaian & 96,63 & Baik Sekali \\
\hline 8. & Respon Guru Uji Coba Pemakaian & 96,97 & Baik Sekali \\
\hline 9. & $\begin{array}{c}\text { Tes Lisan Sesudah Menggunakan } \\
\text { Media Uji Coba Pemakaian }\end{array}$ & 86,11 & Baik Sekali \\
\hline
\end{tabular}

B. Revisi Setelah Penilaian Ahli Media

1. Revisi dari ahli media adalah desain papan, perbaikan kartu dolanan scrabble, dan perbaikan buku petunjuk. Revisi Setelah Penilaian Ahli Materi.

2. Revisi dari ahli materi adalah kalimat Tanya dalam kartu dolanan scrabble, bahasa pada buku petunjuk, dan perbaikan pada kunci jawaban.

3. Revisi Setelah Penilaian Ahli Pembelajaran. Tidak ada revisi pada bagian media. Revisi yang diberikan ahli pembelajaran adalah revisi pada RPP.

Pengembangan media Scrabble Bahasa Krama untuk mata pelajaran Bahasa Jawa kelas lima SD Negeri 2 Petir telah selesai dikembangkan. Proses pengembangan media ini dilakukan mengacu pada model pengembangan Thiagarajan dengan empat langkah. Empat tersebut yaitu Define (pendefinisian), Design (perencanaan), Dovelopment (pengembangan), dan Dissemination (penyebaran).

Penilaian yang diperoleh dari ahli media, ahli materi dan ahli pembelajaran didapatkan rata-rata 88,76 dengan kategiri Baik Sekali. Selanjutnya penilain dari uji coba produk didapat dari respon guru dan siswa serta tes lisan sesudah menggunakan media adalah 96,88 dan 93,33 serta 95 yang termasuk kategori Baik Sekali. Kemudian pada uji coba pemakaian didapatkan pula nilai dari respon guru, siswa dan tes lisan sesudah menggunakan media dengan nilai 96,63 dan 88,37 serta 86,11 yang termasuk dalam kategori Baik Sekali. Selanjutnya Data keseluruhan dari semua penilaian terhadap kualitas dan kelayakan media Scrabble Bahasa Krama dapat digunakan untuk mendukung keterampilan berbicara bahasa Jawa krama siswa kelas lima SD Negeri 2 Petir termasuk dalam kategori Baik Sekali.

\section{SIMPULAN}

Berdasarkan hasil penelitian dan pengembangan media Scrabble Bahasa Krama untuk mendukung keterampilan berbicara siswa kelas lima SD Negeri 2 Petir, maka dapat disimpulkan bahwa: 
1. Langkah-Langkah Pengembangan

Penelitian dan pengembangan media Scrabble Bahasa Krama mengacu pada model pengembangan menurut Thiagarajan dengan model pengembangan 4D yang terdiri dari pendefinisian (Define), perencanaan (Design), pengembangan (Dovelopment), penyebaran (Dissemination). Pendefinisian (Define) adalah mengumpulkan data dan menanalisis kebutuhan. Perencanaan (Design) adalah merencanakan produk yang akan dikembangkan sesuai dengan analisis kebutuhan. pengembangan (Dovelopment) adalah proses pengembangan media termasuk melakukan validasi ahli media, ahli materi, ahli pembelajaran untuk mengetahui kelayakan media kemudian digunakan untuk uji coba produk dan uji coba terbatas.

2. Kelayakan media Scrabble Bahasa Krama.

Media Scrabble Bahasa Krama yang dikembangkan diujikan kepada ahli media, ahli materi, dan ahli pembelajaran. Pada tahap validasi media mendapatkan jumlah skor 59 sehingga dapat dihitung menggunakan rumus dan mendapat nilai 77,63 dengan kategori "Baik". Pada tahap validasi materi mendapatkan jumlah skor 65 sehingga dapat dihitung menggunakan rumus dan mendapat nilai 95,59 dengan kategori "Baik Sekali". Pada tahap validasi pembelajaran mendapatkan jumlah skor 67 sehingga dapat dihitung menggunakan rumus dan mendapat nilai 93,06 dengan kategori "Baik Sekali". Total keseluruhan nilai dari ahli media, materi, dan pembelajaran adalah 266,28 kemudian dihitung menggunakan rumus rata rata dan didapat nilai 88,76 dengan kategori "Baik Sekali".

Tahap uji coba produk didapatkan skor dari pengisian angket respon siswa mendapatkan nilai 96,88 dengan kategori "Baik Sekali"dan respon guru mendapatkan nilai 93,33 dengan kategori "Baik Sekali". Hasil tes siswa pada tes lisan sebelum menggunakan media mendapatkan nilai rata-rata 60 dan tes lisan sesudah mengguankan media mendapat nilai rata-rata 95 hasil tersebut menunjukan peningkatan. Tahap uji coba pemakaian didapatkan skor dari pengisian angket respon siswa mendapatkan nilai 96,63 dengan kategori "Baik Sekali"dan respon guru mendapatkan nilai 96,67 dengan kategori "Baik Sekali". Hasil tes siswa pada tes lisan sebelum menggunakan media mendapatkan nilai rata-rata 48,89 dan tes lisan setelah menggunakan media mendapat nilai rata-rata 86,11 hasil tersebut menunjukan peningkatan.

Hasil penilaian secara keseluruhan tersebut masuk dalam kategori "Baik Sekali". Hasil penelitian mengindikasikan bahwa media Scrabble Bahasa Krama memiliki kualitas yang sangat baik. Media Scrabble Bahasa Krama juga dikatakan layak digunakan dalam proses pembelajaran untuk mendukung keterampilan berbicara siswa.

\section{DAFTAR PUSTAKA}

Arsyad, Azhar. 2016. Media Pembelajaran. Jakarta: PT Raja Grafindo Persada.

DPRRI. 2011. Undang-Undang Sistem Pendidikan Nasional No. 20 tahun 2003. Jakarta.

Edi Roesdiono. 2012. Main Scrabble Untuk Mendongkrak. Volum Kosakata. Kompassiana.com diakses pada 12 Desember 2017 Pukul 12.34.

Kunandar. 2014. Penilaian Autentik (penilaian hasil belajar peserta didik berdasarkan kurikulum 2013). Jakarta: Rajawali Pres

Nurseto, Tejo. 2011. Membuat Media Pembelajaran yang Menarik. Jurnal Ekonomi\& Pendidikan. Volum 8 Nomor 1.

Permendikbud. 2014. Permndikbut nomor 79 Tahun 2013 Tentang Muatan Lokal Kurikulum 2013. Jakarta. 
Perpendik, 2013. Peraturan Gubernur Daerah Istimewa Yogyakarta nomor 64 Tahun 2013. Yogyakarta.

Siregar, Syofian. 2014. Statistik Deskriptif Untuk Penelitian. Jakarta: PT Raja Grafindo Persada.

Sugiyono. 2016. Metode Penelitian dan Pengembangan. Bandung: Alfabet.

Widoyoko, Eko Putra. 2017. Evaluasai Program Pembelajaran. Yogyakarta: Pustaka Pelajar. 